\title{
Engineering Economy Analysis on the Production of Iron Ore in Nigeria
}

\author{
R. A. Adebimpe ${ }^{1^{*}}$, J. M. Akande ${ }^{2}$ \\ ${ }^{1}$ The Federal Polytechnic, Ado-Ekiti, Deparment of Mineral Resources Engineering, Ado-Ekiti, Nigeria \\ ${ }^{2}$ Federal University of Technology, Akure, Dept of Mining Engineering, Ado-Ekiti, Nigeria \\ E-mail: rasheed4u1@yahoo.com \\ Received February 24, 2011; revised March 2, 2011; accepted March 22, 2011
}

\begin{abstract}
In line with the Federal government decision to attract direct foreign investment to the solid mineral sector and to further diversify the Nigerian economy; this study used the discounted cash flow micro-economic assessment to evaluate large-scale iron ore production in Nigeria. The iron ore project has an initial investment cost of US\$ $73.934 \mathrm{~m}$, annual expenditure and benefit of US\$ $48.128 \mathrm{~m}$ and US\$270 m respectively. The net present value (NPV), internal rate of return (IRR) and payback period of financial analysis at $100 \%$ capacity utilizations are US\$ $833.10 \mathrm{~m}, 444.36 \%$ and 6 years respectively. The economic assessment also shows a positive NPV at both $75 \%$ and $60 \%$ capacity utilizations. The study further show that the iron ore project has good economic potential and will also guide potential investor(s) in making decision on whether or not to commit resources to the project.
\end{abstract}

Keywords: Iron Ore, Micro-Economic Assessment, Solid Mineral Sector, Nigeria

\section{Introduction}

The decision to develop a particular deposit is based on the net present value (NPV) [1]. NPV is one of the micro-economic assessment tool used to evaluate the feasibility of project and it must be positive for a project to be considered worthwhile. The use of discounted cash flow analysis is a tool in the economics of the mining industry in the last 30 years, it has become common to define an ore reserve as that part of a mineral resource whose exploitation can generate maximum net present value (NPV) or return on investment [2]. NPV entails forecasting the stream of future net revenues a mineral resource would generate if exploited optimally, and then discounting this revenue stream using appropriate cost of capital [3].At the planning stage of a mining project it is necessary to gather relevant data and also determine factors that would influence the attainment of the highest NPV.The objective of the planning process for an open pit mine is usually to find optimum annual schedules that will give highest net present value(NPV) while meeting the various production, blending, sequencing and pit slope constraints[4]. Determining the feasibility of a mineral property may be simple or sophisticated but has one primary goal and this is to demonstrate that the project is economically viable if it is designed and operated appropriately [5]. Iron ore occurrence has been established in Itakpe, Ajabanoko, Agbaja, Chokochoko, Agbade Okude and Nsude hills (Figure 1; Table 1). The ore reserves vary from two billion tons to thirty million tons and the deposits are of the type's hematite-magnetite, heamatite-geothite and siderite goethite [6]. However out of the iron ore deposits listed above only the Itakpe iron ore mine have so far been developed and it started production in 1979.The exploitation of the iron ore includes the following process: i) development of the access roads, the creation of benches,platforms,safety ramps and the development of safe and economically acceptable slope faces; ii) drilling and blasting of the benches; iii) truck haulage of the run-of-mine to the crushing plant; iv) truck haulage of the crushed rock to the beneficiation plant, and v) beneficiation of the iron ore. The National Iron Ore Mining Project (NIOMP) was established to exploit the Itakpe iron ore deposit. The corporate objectives of NIOMP are listed as follows [7]: i) to produce and supply $100 \%$ of the iron ore requirements of the Ajaokuta Steel Company Limited (ASCL) amounting to $2.15 \times 10^{6}$ tons per year assaying $63 \% \mathrm{Fe}$ ii) to produce and supply $40 \%$ of the iron ore requirements of the Delta Steel Company, Aladja (Warri) (DSC) amounting to 


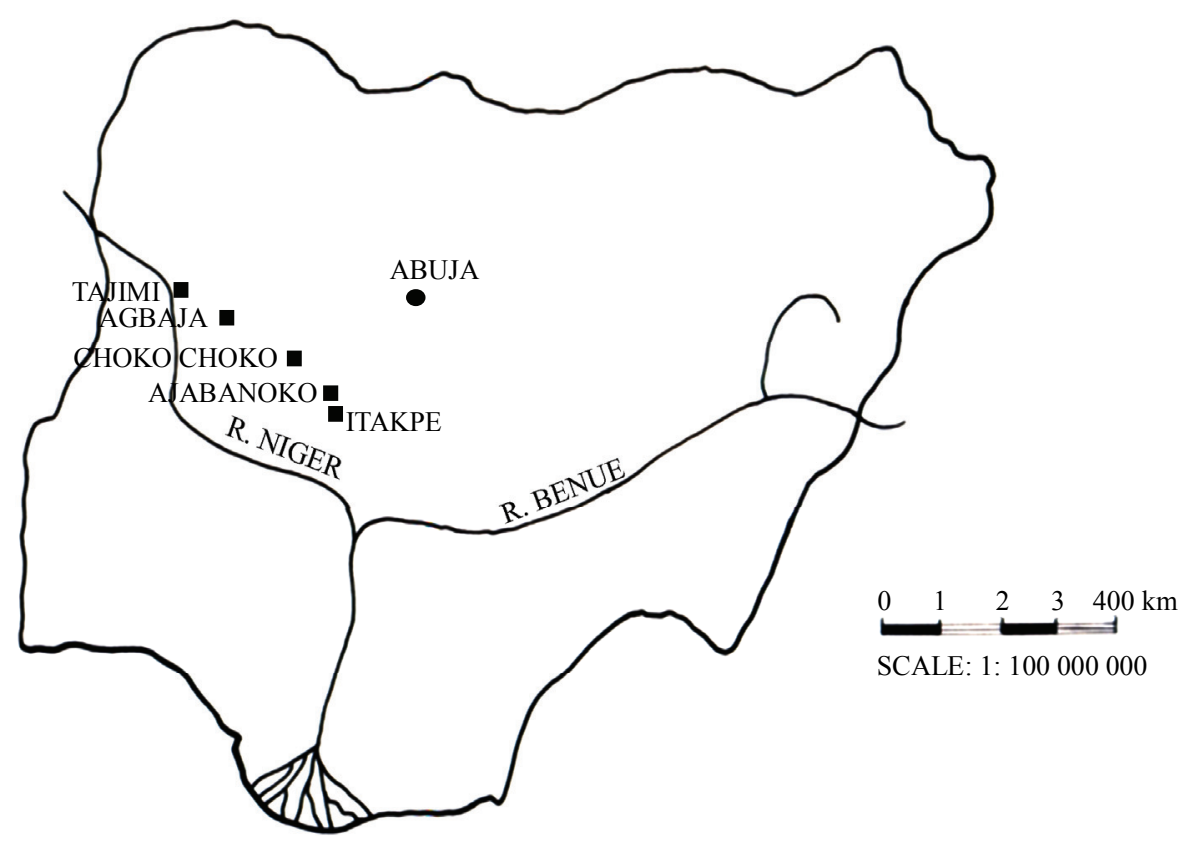

Figure 1. Location of the study orea.

Table 1. Iron ore reserves in Nigeria.

\begin{tabular}{clcc}
\hline S/No & \multicolumn{1}{c}{ Location } & \% Fe Content & Reserve (tons) \\
\hline i & Agbaja & $45-54$ & 2 billion \\
ii & Itakpe & 36 & 200 million \\
iii & Ajabanoko & 35.61 & 62.5 \\
iv. & Chokochoko & 37.43 & 70 million \\
v. & Agbade-Okudu & 37.43 & 70 million \\
vi & Nsude Hills & 37.43 & 60 million \\
\hline
\end{tabular}

Mines Department [6]

550000 tons per year assaying $67 \%$ to $68 \% \mathrm{Fe}$ as per initial design of Itakpe plant iii) to export the concentrates to the international market after local needs have been satisfied iv) to represent the interest of the Federal Government of Nigeria in foreign iron ore mining projects v) to arrange and coordinate the exploitation of other locally available raw materials required by the major steel plants. To achieve the objectives listed above, a careful investment analysis must be carried out. Mine investment analysis is a complex exercise because of project uncertainty; such as mineral price and deposit quality and physical structure of the mineral deposit [8]. The economic analysis must answer to two important questions i) does the investment project satisfy the objectives of the firm? ii) and how does this project compare with other investment opportunities? [9].

The Itakpe iron ore deposit comprises of twenty- five (25) ore layers. According to dip, strike, attitude and location, fourteen (14) layers of iron ore have been grouped, they can be found within four (4) groups; Northern, Central, Intermediate and Southern.

From a tectonic point of view, the Itakpe deposit is confined to the southern limb of a large Itakpe-Ajabanoko anticline with enclosing rocks and conformable ore layers striking sub-latitudinally and slightly bending to the north and dipping southward at angles ranging from $40^{\circ}$ to $80^{\circ}$ with local minor-fold complications [10]. The average iron ore content of the ore deposit was determined to be approximately $35 \%$ [11]. It has an estimated iron ore reserve of 200 million tons. The study therefore is to determine the economic viability of iron ore production in Nigeria. It is expected that the result will guide prospective investors or entrepreneurs before committing their resources into iron ore production in Nigeria. 


\section{Methodology}

\subsection{Engineering Economy Studies}

The purpose of engineering economic studies is to establish whether a technically feasible project is also economically viable $[12,13]$.

\subsection{Data Collection}

The study assessed a large scale iron ore production from Itakpe iron ore deposit. The annual run-of-mine production per year is 7.374 million tons while the annual production at the beneficiation plant is 2.7 million tons (Table 2). Facilities for the project were identified and their cost estimates were obtained from equipment fabricators and suppliers. The operating (equipment running, drilling. blasting, loading, haulage, maintenance costs, office overheads and other administrative charges) were estimated and categorized as production and overhead cost.

The gradient series model was used to estimate the annual operating cost over the economic life cycle $(n)$ of the iron ore mine. In the model, the annual operating cost of the project was assumed to be $A_{1}$ in the first year and $G$ more naira for each additional year until the end of the twenty-seventh year for Itakpe iron ore mine. The Present Worth-Cost $(P W-C)$ of annual operating expenses was first estimated and there-after converted to Annual Worth-Cost $(A W-C)$ using the expression, after DeGarmo et al., (1979).

$$
\begin{aligned}
& P W-C=A_{1}(P / A, i, n)+G(P / G, i, n) \\
& A W-C=P W-C x(A / P, i, n)
\end{aligned}
$$

Where: $\mathrm{i}$ is the Minimum Attractive Rate of Return (MARR), and the factors $(P / A, i, n)$, the uniform series present worth factor, $(P / G, i, n)$, the gradient worth conversion factor, and $(A / P, i, n)$, the capital recovery factor were obtained from the interest table. $A_{1}$ and $G$ were estimated by the author as US\$ 48.128 million and US\$
16.043 million respectively, for the Itakpe iron ore mine operating at full capacity. The MARR, $i$, of $9.44 \%$ as calculated below was used in the analysis. It was adjusted for inflation using Equation 3:

$$
i=[(100+P) /(100+a) \times 100]-100
$$

where

$$
\begin{aligned}
& P=\text { the average market rate of interest }=24 \% \\
& a=\text { rate of inflation }=13.3 \% \quad[15] \\
& i=[(100+24) /(100+13.3) \times 100]-100=9.44 \%
\end{aligned}
$$

The number of employees required for the project at various capacity utilization was estimated and their wages also estimated on the basis of experience, qualification and situation at the Nigerian labour market. All estimates were made in dollars. The economic output expected from the project is the sales of $64 \% \mathrm{Fe}$ at the international market price of US\$100/ton. This and the salvage value at the end of the project life cycle, put at 27 years for Itakpe iron ore mine. The financial estimate of the output was based on the prevailing market price, exclusive of VAT.

\subsection{Approach to Data Analysis}

\subsubsection{Net Present Value (NPV)}

The model was used to determine the profitability of the project before tax [12]. The $N P V$ model refers to the equivalent of $a$ single sum of money to be received or disbursed at $t=0$, if all future receipts and expenses over time are discounted to the present time. The model is specified as

$$
N P V=\sum_{t=0}^{n} A_{t}(1+i)^{-t} \equiv \sum_{t=0}^{n} A_{t}(P / F, i, n)
$$

where $A_{\mathrm{t}}$ is the net cash flow in the year $(t), i$ is the cut-off discount rate while $\mathrm{n}$ is the economic life cycle, and the factor $(P / F, i, n)$, the single payment per cent worth, is also obtained from the interest table. If $N P V$ is positive, then the project can be accepted.

Table 2. Open pit technical parameters.

\begin{tabular}{ll}
\hline \multicolumn{1}{c}{ Parameter } & \multicolumn{1}{c}{ Itakpe iron ore mine } \\
\hline i. Pit length & $4 \mathrm{~km}$ \\
ii. Pit depth & $250 \mathrm{~m}$ \\
iii. Ore reserve & 200 million tons \\
iv. Life span & 27 years \\
v. Annual rom production & 7.373 million tons \\
vi. Annual waste production & 29.492 million tons \\
vii. Waste to ore ratio & $4: 1$ \\
viii. Daily ore production & 30721.44 \\
ix. Daily waste production & 122885.76 \\
x. Average ore grade & $36 \%$ \\
xi. Minimum width of pit bottom & $50 \mathrm{~m}$ \\
xii. Ultimate pit slope & 72 \\
\hline
\end{tabular}




\subsubsection{Internal Rate of Return (IRR)}

The IRR solves for the interest rate that equates the equivalent of cash inflow to the equivalent worth of cash outflow [13]. Using the present worth model after [16], the IRR is the discount rate, irr that makes the $N P V$ equal to zero. Its calculation formula is:

$$
\sum_{t=o}^{n} A_{t}(1+i r r)^{-t}=\sum_{t=o}^{n} A_{t}(P / F, i r r, n)=0
$$

The IRR criterion reflects the profitability of the project [16]. The project is acceptable when the irr $\geq i$, the MARR, otherwise not accepted $[12,13,16]$.

\subsubsection{The Discounted Payback Period $\left(P_{t}\right)$}

This model determines the period of time, starting from the first day of the investment period, required to fully recover the investment and operation cost [16]. And such determination, to be meaningful, must be made on an after-tax basis, sometimes with the project salvage value ignored [12]. The model is specified in present worth as[16]:

$$
\sum_{t=1}^{P_{\mathrm{t}}}\left(C_{b}-C_{c}\right)(1+i)^{-t}=\sum_{t=1}^{P_{t}}\left(C_{b}-C_{c}\right)\left(P / F, i, P_{t}\right)=0
$$

where, $C_{b}$ is the cash benefit of the investment, $C_{c}$ is the cash cost of the investment.

Payback as a decision tool is used to measure how risky a project is [12]. In evaluating the payback period, a $30 \%$ corporate tax on gross earnings has being used; with the project salvage value ignored. The iron ore project is acceptable if the maximum acceptable payback period, $P_{t(\max )}>P_{t}$ otherwise not. In this study $P_{t(\max )}$ has being set equal to the life-cycle of the project .

\subsection{Mine Economic Investment Model}

The following mine economic investment model has been used in the estimation of the various costs associated with exploitation of the iron ore [17-19].

Equipment cost $(\$ \mathrm{~m})$

$=6000$ (tons of deposit and waste mined daily) ${ }^{0.7}$

+5000 (tons of deposit and waste mined daily) $)^{0.5}$

Maintenance cost $(\$ \mathrm{~m})$

$=\$ 150000$ (tons of deposit and waste mined daily) $)^{0.3}(8)$

Labour cost

$=\$ 58.563$ (tons of deposit and waste mined daily) ( $^{-0.5}$

$+\$ 3.591$ (tons of deposit and waste mined daily) ${ }^{-0.3}$

Supplies cost $(\$)$

$=\$ 13.40$ (tons of deposit and waste mined daily) $)^{-0.5}$

$+\$ 1.24$ (tons of deposit and waste mined daily) $)^{-03}$
$+\$ 0.90$ (tons of deposit and waste mined daily) ${ }^{-0.2}$

Daily crushing cost $=\$ 7.90 \times T^{0.6}$

Daily grinding cost $=\$ 4.90 \times T^{0.8}$

Daily processing cost $=\$ 54 \times T^{0.6}$

Daily tailing cost $=\$ 0.92 \times T^{0.8}$

Electrical power cost $=\$ 145 \times T^{0.56}$

Drilling cost per ton $=\$ 1.90 T_{p}^{-0.3}$

Blasting cost per ton $=\$ 3.17 T_{p}^{-0.3}$

Loading cost per ton $=\$ 2.67 T_{p}^{-0.3}$

Haulage cost per ton $=\$ 18.07 T_{p}^{-0.3}$

\subsection{Personnel Calculation}

Number of open pit personnel (Nop) $=0.034 \times T_{p}(20)$

Number of mill personnel $(\mathrm{Nmp})=7.2 \times T^{0.3}$

Number of service personnel (Nsv)

$=0.254 \times(\mathrm{Nop}+\mathrm{Nml})$

Number of administrative and technical personnel,

$\mathrm{N}_{\mathrm{at}}=0.11(\mathrm{Nop}+\mathrm{Nml}+\mathrm{Nsv})$

\section{Results and Discussion}

Table 3 presents the list of facilities and civil structures required for the iron ore project at a large-scale level. The project is estimated to have a production capacity of 7373145.6 tons per annum working 6 days per week running three shifts per day. The initial investment (or first cost), US $\$ 73.934 \mathrm{~m}$ is made up of pre-production expenses, which include site allocation (including mining lease), prospecting activities and capital investment including installation expenses (Table 4). The annual operating cost includes cost of labour, maintenance, field consumables, raw materials and equipment running cost, estimated at US\$ $48.128 \mathrm{~m}$ for the first year at $100 \%$ capacity utilization (Table 4). The iron ore mining project will require 314 number of staff; this include 132 open pit personne 1,94 mill personne 1,57 service personnel and 31 administrative and technical staff. Their wages in the first year will amount to $\$ 1.641 \mathrm{~m}$ while ore processing costs were estimated at US\$ $7.821 \mathrm{~m}$. The NPV of the iron ore project at $100 \%$ production capacity is US\$ 833.10 million which is greater than zero. The profitability analysis as seen from Table 3 shows a positive NPV before tax when the mine is operated and will make profit at 60,75 and $100 \%$ capacity utilization. 
The project IRR is $444.36 \%$, which is greater than the present cut-off discount rate of $09.4 \%$. This indicates that the project is worthy of investment and has the ability to make profit. The payback period before tax is 6 years, which shows that the project has a good feature of not being a risk as first and operating costs of the project can be recovered under a short duration of 6 years when compared with the economic life cycle of the project of 27 years (Table 5).

\subsection{Sensitivity Analysis of Factors Affecting the Economic Benefit of the Iron Ore Project in Nigeria}

Sensitivity analysis was carried out on the iron ore project to determine its impact on the profitability of project. Two factors affecting the IRR at $100 \%$ capacity utilization were considered (Table 6). The two sensitivity factors are initial investment and price of iron. The IRR of the project was evaluated using a $20 \%$ variation. The IRR of the project will decrease from $444.36 \%$ to $424.42 \%$ if the initial investment cost is increased by $20 \%$ and will increase to $456.80 \%$ if the initial investment cost decrease by $20 \%$. Also the IRR of the project will increase to $469.60 \%$ if the revenue from sales of iron ore is increased by $20 \%$ while it will decrease to $331.13 \%$ if the revenue from sales of iron ore decrease by $20 \%$ With the IRR of varied factors greater than $9.44 \%$, the MARR, this shows that the two factors if varied in cost by $20 \%$ will affect the IRR and or the profitability of the project significantly. Hence the order of sensitivity factors affecting the economic benefit of the project is: the price of iron ore, followed by the initial investment cost. The result of this sensitivity analysis shows that a decrease in costs and an increase in price of iron ore increase the project's profitability, while an increase in costs and a decrease in price of iron ore decrease the profitability of the project.

Table 3. Facilities and civil structures (Itakpe iron ore mine).

\begin{tabular}{|c|c|c|c|c|c|}
\hline S/No & Equipment description & Capacity & Quantity & Unit price(US\$m) & Total cost(US\$m) \\
\hline 1 & Dump truck & 100 tons & 20 & 0.78 & 15.6 \\
\hline 2 & Wheel Loader & $8 \mathrm{~m}^{3}$ & 6 & 0.973 & 5.84 \\
\hline 3 & Excavator & $5.6 \mathrm{~m}^{3}$ & 3 & 0.42 & 1.26 \\
\hline 4 & Bulldozer & $\operatorname{Max} 15 \mathrm{~m}^{3}$ & 2 & 0.46 & 0.92 \\
\hline 5 & Scraper & & 2 & 0.1 & 0.2 \\
\hline 6 & Pneumatic drill rig & $15 \mathrm{~m} / \mathrm{h}$ & 8 & 0.1 & 0.80 \\
\hline 7 & Rotary drill rig & & 2 & 0.86 & 1.72 \\
\hline 8 & Jack Hammer & $3 \mathrm{~m} / \mathrm{h}$ & 8 & 0.003 & 0.027 \\
\hline 9 & Compressor & 8 bar & 4 & 0.047 & 0.187 \\
\hline 10 & Water tanker & 5000 gallon & 2 & 0.047 & 0.094 \\
\hline 11 & Admin. Car & & 6 & 0.04 & 0.24 \\
\hline 12 & Workshop van & & 6 & 0.033 & 0.2 \\
\hline 13 & Gyratory crusher & & 1 & 0.689 & 0.689 \\
\hline 14 & Primary crushing plant & & 1 & 20.76 & 20.76 \\
\hline 15 & Process capital cost & & 1 & 21.21 & 21.21 \\
\hline 16 & Construction access road & & $8 \mathrm{~km}$ & 0.163 & 1.304 \\
\hline 17 & Staff buses & & 4 & 0.08 & 0.32 \\
\hline 18 & Factory housing and offices & & 1 & 0.133 & 0.133 \\
\hline 19 & Incidental & & & & 1.77 \\
\hline Total & & & & & 73.274 \\
\hline
\end{tabular}

Table 4. Cashflow (US \$m) for Itakpe iron ore project.

\begin{tabular}{lccc}
\hline \multicolumn{1}{c}{ Cost factor } & Capacity A & Capacity B & Capacity C \\
\hline Initial investment Capital investment & 73.274 & 73.274 & 73.274 \\
Pre-production expenses & 0.66 & 0.66 & 0.66 \\
Sub total & 73.934 & 73.934 & 73.934 \\
Annual Operation expenses Production costs & & & 1.947 \\
Drilling costs & 1.168 & 1.460 & 3.249 \\
Blasting cost & 1.949 & 2.437 & 2.737 \\
Loading costs & 1.642 & 2.052 & 18.521 \\
Haulage costs & 11.11 & 13.891 & 6.816 \\
General service cost & 4.089 & 5.112 & 5.396 \\
Maintenance cost & 3.238 & 4.047 & 7.821 \\
Ore processing cost & 4.693 & 5.866 & 1.641 \\
Salary of admi. and tech. staff & 0.985 & 1.231 & 48.128 \\
Sub total & 28.874 & 36.096 & 270 \\
Annual Revenue Sales of iron ore & 162 & 202.5 & 8.64 \\
Savage value & 15.12 & 10.8 & 833.10 \\
NPV & 471.33 & 606.76 & \\
\hline
\end{tabular}


Table 5. Result of other economic assessment of the Itakpe iron ore mine.

\begin{tabular}{lc}
\hline \multicolumn{1}{c}{ Profitability index at $i=9.44 \%, n=27$ years } & Economic assessment \\
\hline Internal rate of return IRR(\%) & 444.36 \\
Payback period (Years) & 6 \\
\hline
\end{tabular}

Table 6. Result of sensitivity analysis of Itakpe iron ore mine.

\begin{tabular}{cccc}
\hline Factor & IRR(\%)Original state & Variation & Varied rate of IRR(\%) \\
\hline Initial investment cost & 444.36 & increase by 20\% & 424.42 \\
& & decrease by 20\% & 456.80 \\
Revenue from iron ore & 440.36 & increase by 20\% & 469.60 \\
\hline
\end{tabular}

From the results of this micro-economic analysis, investment in this large-scale iron ore project in Nigeria becomes infeasible in financial terms of $I R R_{\text {finance }}<$ $09.44 \%$, the MARR of the project.

\subsection{Government Policy to Stimulate Growth in the Solid Mineral Sector of Nigeria}

The ministry of mines and steel development has worked a package of incentives for potential investors in the solid mineral sector and is embedded in the Mineral Act, 2007 [20] .Some of these include: i) Exemption from payment of customs and import duty in respect of plant, machinery, equipment and accessories imported specifically and exclusively for mining operation ii) expatriate quota and resident permit in respect of the approved expatriate personnel iii) personnel remittance quota for expatriate for personnel, free from any tax imposed by any enactment for the transfer of external currency out of Nigeria iv) the Act provides a tax relief period of 3 years for any company granted a Mineral Title under the Act and can be extended for a further period of 2 years v) Section 30 of the Act provide for deductibility of environmental cost.

\section{Conclusion}

The study has confirmed that the production of iron ore in Nigeria is economically viable. With the introduction of non-renewable period of a 5-year tax holiday on corporate income in Nigeria, the micro-economic profitability of the project is expected to increase, therefore making investment in the iron ore enterprise more worthwhile for investors.

\section{References}

[1] B. O'Reagan, and R. Moles, "Investment decisions of international mining firms: Policy approaches," Simula- tion. Vol. 78, No. 6, 2002, pp. 362-379.

[2] S. Iloiu, and M Iloiu, "Ore reserve estimation and project profitability," Annals of the University of Petrosani, Mechanical Engineering, Vol. 10, 2008, pp. 85-88.

[3] E. V Domingo, and E. E. P Lopez-Dee, "Valuation methods of mineral resources," $11^{\text {th }}$ Meeting of the London Group, Pretoria, South Africa, 26-30 ${ }^{\text {th }}$ March, 2007. pp. 7.

[4] K. Dagdelen, "Open pit optimisation -Strategies for improving economics of mining projects through mine planning," $17^{\text {th }}$ International Mining Congress and Exhibition of Turkey- IMCET 2001.Turkey. pp. 117.

[5] S. Rupprecht, "Establishing the feasibility of your proposed mining venture," International Platinum Conference 'Platinum adding value'. The South African Institute of Mining and Metallurgy, South Africa, 2004, pp. 243.

[6] Mines Department,"Inventory of Nigerian minerals, mines and miners,"Federal Ministry of Petroleum and Mineral Resources. Lagos, 1993, pp. 1-10.

[7] U. Turaki, "Management of the mineral sector in a depressed economy," NIOMP experience. Nigerian Mining Journal. Vol. 2, No. 1, 1997, pp. 12-19.

[8] M. Samis, "Valuing a multi-zone as a real asset portfolio-A modern asset pricing(real options) approach," $5^{\text {th }}$ Annual International Conference on real options-theory meets practice. Los Angeles, California, United States, 13-14 ${ }^{\text {th }}$ July, 2001. pp. 1.

[9] D.,Csiminga, and M. Iloiu, "Economic analysis of mining projects," .Annals of the Oradea University. Fascille of Management and Technological Engineering, Volume VI(XVI), 2007. pp. 2094.

[10] A. O, Solomon, O. A Adewole, A. U, Garba, A. A Odunaike, S. M, Kollere, and P. O Ajiboye, "Study on magnetic concentration of Nigerian Itakpe sinter concentrate to a Midrex-grade concentrate," Maejo International Journal of Science and Technology. Vol. 3 No. 03, 2009, pp. 400-407.

[11] P. U Umunakwe, "Developing a new mine-The Itakpe case," Proceedings of the annual conference of Nigeria mining and geosciences society, Jos, 1985, pp.

[12] E. P. DeGarmo, J. R. Canada, and W. G. Sullivan, "Engineering economy," $6^{\text {th }}$ edition. Macmillan, New York. 
1979.

[13] M. O Ilori, I. A. Irefin, and A. A Adeniyi,. "Engineering economy studies on the production of non-alcoholic beverages from some tropical crops," Technovation. Vol. 17, No. 11/12, 1997, pp. 715-721.

[14] T. "Agboola, Naccima decries high interest rate,"The Nation(02/04/2009). Lagos.

[15] O. Chiama, "Inflation slows further to $13.3 \%$,"The Nation.(20/05/2009) Lagos.

[16] O Adeoti,., M. O., Ilori, T. O Oyebisi,. and L. O Adekoya, "Engineering design and economic evaluation of a family-sized biogas project in Nigeria," Technovation, Vol. 20, 2000, pp.103.
[17] T. A. O' Hara, "Quick guide, to the evaluation of ore bodies," CIM Bulletin (no 814) 73 (2), 1980, pp. 87-89.

[18] T. A. O' Hara, and S.C. Suboleski, “Chapter 6:3: costs and cost estimation," In: H.L Hartman, (Senior Editor): SME mining Engineering Handbook $2^{\text {nd }}$ Edition (Vol. 1 ), SME, 1992, pp. 405-424.

[19] W. Hustrulid, and M. Kuchta, "Open pit mine planning and design," $2{ }^{\text {nd }}$ Edition. Taylor and Francis London, 2006, pp. 137-152.

[20] Federal Republic of Nigeria, "Nigerian minerals and mining act," Federal Republic of Nigeria., 2007, A479A538. 